archaeological institutions and historical galleries-housing treasures which in Canada one would normally expect to find in an archives. The buildings themselves and their displays are magnificent and attract many visitors. The average Mexican, incidentally, seems much more interested than the average Canadian in such buildings and in his history. Finally, many individual churches have holdings of historically valuable material. Unfortunately, there is no one central source of information as yet which a researcher may consult concerning these resources.

Within the Secretariat of the Presidency is the Office of Administrative Studies. This Office commissioned our study and had earlier initiated others in the records management area. It has now established working groups to identify problem areas and to recommend solutions, and has established an excellent working relationship with the various records managers of the secretariats. The Office of Administrative Studies is determined that records and archival management shall be raised to a high level of competence within the various secretariats of the Mexican government. The report which we shall be submitting should be of help in achieving that goal.

W.W. Bilsland

Public Archives of Canada

\title{
Australian Society of Archivists
}

During the biennial conference of the Library Association of Australia at Perth in August 1973, archivists were invited to meet and discuss a proposal advanced by Michael Saclier of the Australian National University Archives calling for an archivists' association. At this meeting a steering committee was formed "to investigate and promote the formation of an association of archivists". Through a series of newsletters, the steering committee reported to archivists throughout Australia, and local meetings were held in all the main centres to encourage archivists to discuss and vote on proposals put forward by the committee. As a result, the Australian Society of Archivists was formed and the inaugural meeting was held in Canberra, 5 and 6 April 1975.

The objectives of the Society fall into two categories. It is seen as a professional society for archivists in Australia and the Pacific region which will be concerned with basic professional matters including the preservation and care of archives, standards of archival practice and administration, professional conduct amongst archivists, archival qualifications and professional training, the publication of a journal and other material, the promotion of a professional identity among archivists and the advancement of professional standing and welfare. 
The Society is also envisaged as providing a medium of "communication and cooperation between archivists, the institutions in which they work and the users of archives"'; promoting understanding outside the profession of the nature and value of archives; encouraging the efficient and responsible use of archives; and cooperating with other organizations having complementary objectives in such fields as library science, conservation, historical research, and records management.

To achieve the first of these objectives, it was decided that control of the Society must remain in the hands of the archival professionals. There are, therefore, three classes of membership-professional, associate, and institutional. Only professional members may hold office and vote in elections and at general meetings. Associate and institutional members are, however, entitled to all other privileges of membership including the right to attend and speak at general meetings, conferences, and seminars.

The Society publishes a Bulletin every two months and will begin publication of its journal in February, 1976. This journal will probably be Archives and Manuscripts, the existing journal of the Archives Section of the Library Association of Australia, and negotiations for the transfer are now (October, 1975) almost completed. Regional meetings have already been held in some areas to form local units of the national body.

Any inquiries concerning the Society should be addressed to the association's Secretary, Miss P. Quinn, Bank of New South Wales Archives, P.O. Box 13, Pyrmont, N.S.W. 2009, Australia. Articles for submission to the Society's journal should be sent to the Editor, Mr. A. Lemon, 704 Toorak Road, Malvern, Vic. 3144, Australia.

$$
\begin{gathered}
\text { P. Quinn } \\
\text { Australian Society } \\
\text { of Archivists }
\end{gathered}
$$

\section{International Congress on Archives}

The Eighth International Congress on Archives, sponsored by the National Archives and Records Service of the United States and the Society of American Archivists, will be held in Washington, DC, 27 September to 1 October 1976. The theme of the Congress plenary sessions will be "The Archival Revolution of Our Time"'. Papers presented in the sessions will deal with records management, technological advances in archives, access, and international archival cooperation.

The Society of American Archivists will hold its annual meeting concurrently with the Congress in Washington. Registrants for either meeting will be able to participate in the program sessions of both 